Zusammenfassung. Untersucht wurden 3 Kollagenimplantate: Lösungsmittel getrocknete Dura, Fascia-lataStreifen, Glycerin-Soft-Dura im Hinblick auf physikalisch-chemische Eigenschaften, morphologische Kennzeichen, zeitlicher Ablauf der Transformation nach Implantation, Indikation und klinische Beurteilung. Unterschiede bestehen in der Dehnung bei Höchstkraft, in der Elastizitätsgrenze und in der Stichausreißfestigkeit. Rasterelektronenmikroskopisches Bild ergibt lineare Anordnung und engmaschige Vernetzung der kollagenen Fibrillen analog der Nativdura bei Lösungsmittel getrockneter Dura. Streng lineare Ausrichtung kollagen verlaufender Fasern in Belastungsrichtung beim Fascia-lata-Streifen. Kein lyophilisiert induziertes Wellenphänomen der kollagenen Fibrillen bei der Glycerin-Soft-Dura, jedoch ist der interfibrilläre Raum mit Glycerin ausgefüllt. Geringste Fremdkörperreaktion und schnellster Umbau erfolgt durch Lösungsmittel getrocknete Dura. Sie ist ein universeller Gewebeersatz. Glycerinimprägnierte Dura hat eine ausgeprägte Fremdkörperreaktion mit Fibrose, Ödem, Exsudat und Hämolyse.

Schlïsselwörter: Lösungsmittel getrocknete Dura - Fascia-lata-Streifen - Glycerin-Soft-Dura - Ersatz von kollagenem Bindegewebe.

\title{
398. Untersuchungen zum Substratstoffwechsel bei septischen Patienten
}

\author{
B. Günther, W. Hartl, M. Wicklmayr und G. Dietze \\ Chirurgische Klinik und Poliklinik der Universität München, Klinikum Großhadern, \\ Marchioninistraße 15, D-8000 München 70
}

\section{Studies on Substrate Metabolism in Patients with Sepsis}

Summary. Substrate metabolism of skeletal muscle was investigated by the forearm technique in 8 patients with sepsis. Compared with patients suffering from postoperative stress, these patients showed lower levels of ketone bodies and free fatty acids. Utilisation of these substrates by muscle tissue was insignificant in this group. Therefore peripheral sparing of glucose did not occur and consequently the lactate release was reduced. The decrease in oxygen uptake in the group with sepsis indicates reduced energy expenditure of skeletal muscle tissue in such conditions.

Key words: Sepsis - Skeletal muscle - Substrate metabolism - Forearm technique.

Zusammenfassung. An 8 septischen Patienten wurde mit Hilfe der Vorderarmtechnik die Stoffwechselfunktion des Skeletmuskels untersucht. Im Gegensatz zu Patienten im postoperativen Stress wiesen die septischen Patienten niedrigere Spiegel an Ketonkörpern und freien Fettsäuren auf. Die Aufnahme dieser Substrate durch den Skeletmuskel spielte keine Rolle. Dadurch trat eine periphere Einsparung von Glucose nicht auf und die Lactatabgabe war in der Folge verringert. Die verminderte Sauerstoffaufnahme weist auf einen eingeschränkten Energieumsatz der Muskulatur in der Sepsis hin.

Schliisselwörter: Sepsis - Skeletmuskel - Substratstoffwechsel - Vorderarmtechnik.

\section{Was ist neu in der Diagnose und Behandlung der Dalgaardschen Trias?}

\author{
L. Cubillos, C. García, J. Mac Kinnon und S. del Villar \\ Krankenhaus der Päpstlichen Katholischen Universität Chiles, Marcoleta 347, Santiago, Chile
}

\section{Advances in Diagnosis and Treatment of Dalgaard's Triad}

Summary. Dalgaard's triad is rare and has been described in autopsy reports; it can now be studied in vivo and various diagnostic techniques are available. Ten patients ( 8 women; mean age 45 years) were studied by computed tomography and ultrasound (US) to evaluate the hepatic and renal involvement. Surgical complications received conservative treatment in keeping with the nature of the disease. Studies of families with abdominal US confirmed a dominant hereditary trait. In one case, a woman who had a stroke, the cerebral angiogram revealed aneurysm of the middle cerebral artery, which was successfully corrected by surgery.

Key words: Hepatorenal polycystic disease - Congenital aneurysm of the circle of Willis - Abdominal ultrasonography - Cerebral angiography.

Zusammenfassung. Die seltene und bei vielen Obduktionen beschriebene Dalgaardsche Trias kann heutzutage ,in vivo" mit modernen diagnostischen Techniken untersucht werden. Zehn Patienten (8 Frauen; Durch- 